\title{
Communication
}

[Comunicação]

\section{Virulence genes in Escherichia coli isolated from feces and urine of cats}

\author{
[Genes de virulência em Escherichia coli isolados de fezes e de urina de gatos] \\ M.W. Caliman ${ }^{1}$ and J.M. Marin ${ }^{2 *}$ \\ ${ }^{1}$ Aluna de pós-graduação - Universidade Estadual Paulista - FCAV-Unesp - Jaboticabal, SP \\ ${ }^{2}$ Universidade de São Paulo - FORP - Ribeirão Preto, SP
}

Cats belong to those species of animals that have been living in close community with man for a long time. Consequently, the interaction between humans and cats is intense, and the possibility of transmitting microorganisms between these different host species is high.

Escherichia coli is a normal inhabitant of the intestinal tract of humans and warm blooded animals. Although usually harmless, various $E$. coli strains have acquired genetic determinants (virulence genes) rendering them pathogenic for both humans and animals. Certain strains of $E$. coli behave as pathogens in dogs and cats, causing gastrointestinal and extra-intestinal diseases (Beutin, 1999). Shiga toxin-producing E. coli (STEC) are among the most important causes of foodborne diseases. They are responsible for a range of human gastrointestinal diseases, including watery or bloody diarrhea. The common feature and main virulence factor of STEC is the production of Shiga toxin-1 (Stx1) and/or Shiga toxin-2 (Stx-2) or its variants (Kaper et al., 2004; Bentancor et al., 2007). Dogs and cats have also been found to carry STEC strains, but their role as bacterial reservoirs has not been completely elucidated. The prevalence of STEC strains among intestinal bacterial strains in pets has been shown to be of highly variable occurrence (Beutin, 1999; Bentancor et al., 2007).

Extra-intestinal pathogenic E. coli (ExPEC) is a major causative agent of uncomplicated urinary tract infection (UTI). Urinary E. coli isolates

Recebido em 25 de março 2013

Aceito em 16 de dezembro de 2013

* Autor para correspondência (corresponding author)

E-mail: jmmarin@ forp.usp.br from domestic cats have repeatedly been reported to share similarities with ExPEC isolated from humans (Johnson et al., 2001). Usually, ExPEC isolates have specialized virulence factors enabling them to colonize host surfaces, injure host tissues, and avoid or subvert host defense systems (Johnson and Stell, 2000). Specific adhesion is mediated by bacterial proteins termed adhesins which may or may not be associated with fimbriae. Pap (pyelonephritisassociated pili), sfa (S fimbrial adhesin) and $a f a$ (afimbrial adhesin) operons are most commonly found encoding respectively $\mathrm{P}, \mathrm{S}$ and Afa (also designated Dr hemaglutinin) adhesins (Le Bouguenec et al., 1992). They are important virulence factors related to adhesion that are usually found among $E$. coli strains causing UTI in humans and animals (Johnson et al., 2008). Thus, the objective of the present study was the isolation of $E$. coli strains from cats and the detection of the virulence gene characteristics of STEC and ExPEC strains.

Samples from cats from Ituverava city, State of São Paulo, Brazil were collected under the supervision of a veterinarian using a rectal sterile cotton swab from diarrheic and non-diarrheic cats, and urine samples were collected using cystocentesis from cats with symptoms of UTI. Swabs were placed into Stuart transport medium, and immediately processed in the laboratory by transferring to MacConkey agar (Difco Laboratories, Detroit, USA) followed by incubation for $24 \mathrm{~h}$ at $37^{\circ} \mathrm{C}$. At least five colonies isolated from each plate (one plate from each cat), it means five samples from each cat 
were submitted to further analyses by standard methods for $E$. coli identification (Koneman et al., 1997). E. coli isolates were grown overnight in nutrient broth (Sigma Chemical Co., St. Louis, USA) at $37^{\circ} \mathrm{C}$ and tested for the presence of $s t x 1$, stx2 and eae genes using the PCR reaction protocol of China et al. (1996) and for the presence of pap, sfa and afa genes according Le Bouguenec et al. (1992). DNA templates were prepared by pelleting $1 \mathrm{ml}$ of each culture by centrifugation $(10000 \mathrm{~g})$, suspending in $250 \mu \mathrm{L}$ of sterile distilled water and boiling for $10 \mathrm{~min}$. After centrifugation, supernatants were used for PCR in an Eppendorf Mastercycler (Eppendorf AG, Hamburg, Germany) to detect stx 1 , st $x 2$, eae, pap, sfa and $a f a$ genes using the primers and PCR conditions according to the above protocols. Reference E. coli strains used as positive control were EDL 933 (O157:H7, stx1, stx2 and eae), EcL 13421 (pap), EcL 6540 (sfa), EcL 13455 (afa); E. coli strain DH5 $\alpha$ was used as the negative control for both reactions. The amplified DNA products were separated by electrophoresis on $1.5 \%$ agarose gels, stained with ethidium bromide and examined under ultraviolet light.

During the 12 month-survey, 40 fecal samples from 21 non-diarrheic and 19 diarrheic cats and three urinary samples from cats with UTI were cultured; 205 E. coli strains were isolated and submitted to PCR analysis to detect stx 1 , st 2 , eae, pap, sfa and afa genes. The isolates possessed genes with combinations of adhesins ( $\mathrm{P}$ and $\mathrm{S}$ fimbriae) and the eae gene involved in attaching-effacing effect (Table 1). None of the E. coli isolates examined by PCR showed the presence of stx 1 or stx 2 genes. The major virulence factor and a defining characteristic of STEC is Stx. This potent cytotoxin not only inhibits protein synthesis in cells, but it also induces the lytic characteristics of programmed cell death (apoptosis) (Kaper et al., 2004). Thus, in the absence of stx genes, it can be presumed that no STEC strains were identified among the E. coli isolates from feces or urine.

Table 1. Virulence factors of $E$. coli isolates from fecal samples of non-diarrheic or diarrheic cats and urine samples from cats with symptoms of urinary tract infections (UTI)

\begin{tabular}{|c|c|c|c|c|c|c|c|c|}
\hline \multirow[b]{2}{*}{ Source } & \multicolumn{8}{|c|}{ Virulence factors - positive strains (\%) } \\
\hline & pap & $s f a$ & $a f a$ & $\begin{array}{c}\text { pap+ } \\
\text { sfa }\end{array}$ & $\begin{array}{c}\text { pap+ } \\
\text { eae }\end{array}$ & $\begin{array}{c}\text { sfa+ } \\
\text { eae }\end{array}$ & $\begin{array}{c}a f a+ \\
\text { eae }\end{array}$ & $\begin{array}{c}\text { Total } \\
(\%)\end{array}$ \\
\hline Fecal & & & & & & & & \\
\hline $\begin{array}{l}\text { Non-diarrheic cats } \\
\left(\mathrm{n}=95^{*}\right)\end{array}$ & 0 & $\begin{array}{c}10 \\
(10.5)\end{array}$ & 0 & $\begin{array}{c}12 \\
(12.6)\end{array}$ & 0 & 0 & 0 & $\begin{array}{c}22 \\
(23.1)\end{array}$ \\
\hline Diarrheic cats $(n=95)$ & $\begin{array}{c}11 \\
(11.5)\end{array}$ & $\begin{array}{c}28 \\
(29.4)\end{array}$ & 0 & $\begin{array}{c}7 \\
(7.3)\end{array}$ & 0 & $\begin{array}{c}3 \\
(3.1)\end{array}$ & 0 & $\begin{array}{c}49 \\
(51.3)\end{array}$ \\
\hline Urine & & & & & & & & \\
\hline Cats with UTI $(n=15)$ & 0 & $\begin{array}{c}3 \\
(20.0)\end{array}$ & 0 & $\begin{array}{c}8 \\
(53.3)\end{array}$ & 0 & 0 & 0 & $\begin{array}{c}11 \\
(73.3)\end{array}$ \\
\hline
\end{tabular}

* number of isolates.

Eighty-two isolates carrying adhesin genes were found, 11 carrying the pap gene (from three diarrheic cats), 41 carrying the $s f a$ gene (from two non-diarrheic, six diarrheic and one UTI cats) and 27 carrying both genes (from four nondiarrheic, two diarrheic and two UTI cats). None of the isolates harbored the afa gene. Each cat had only one type of combination of virulence factors among their isolates. The frequencies of the sfa gene $(20.0 \%)$ and the combination of the pap+ sfa genes $(53.3 \%)$ shown by the E. coli isolates from cats with UTI in Table 1 are quite similar to the results reported by Féria et al. (2001) for cats with UTI, (sfa, 20.0\%; pap+ sfa, $84.0 \%$ ) and by Yuri et al. (1998) for pap+ sfa
(62.0\%). Both authors (Yuri et al., 1998; Féria et al., 2001) reported that, when compared to humans and dogs (Johnson et al., 2001), cats showed little difference between urine and fecal samples in terms of the distribution of virulence genes, which agrees with the results of the present study.

The E. coli gene eae express intimin, which is required for the production of attaching and effacing (AE) lesions in epithelial cells (Kaper $e t$ al., 2004). The eae genes were shown to be essential for intimate adherence and are present in most STEC strains included in the Enterohaemorrhagic E. coli (EHEC) group. 
Attaching-effacing E. coli (AEEC) presenting with AE lesions has been associated with diarrheal illness in dogs and cats (Beutin, 1999). Morato et al. (2009) examined fecal samples from 300 cats for diarrheagenic E. coli types and isolated 15 eae+ E. coli strains from 14 cats (13 non-diarrheic and one diarrheic). They suggested that cats could be a natural reservoir for AEEC strains, serving as a source of transmission of these strains to humans. In the present study, all of the eae+ isolates came from one diarrheic cat, agreeing with Goffaux et al. (2000) who identified AEEC strains as causative agents of diarrhea in cats. Krause et al. (2005) reported that AEEC strains resembling typical enteropathogenic $E$ coli $\left(e a e^{+} b f p \mathrm{~A}^{+}\right)$were isolated from cats in a small number $(6.5 \%)$ of cases, but they concluded that pathogenic AEEC may be transferred to humans by direct contact between animals and humans.
The present study reports a small number (3.1\%) of $E$. coli isolates from one diarrheic cat carrying $s f a+e a e$ genes, both of which are involved with the adherence to epithelial cells. It is not known exactly what this combination means, but the $s f a$ gene may facilitate the fixation of $E$. coli bacteria in the gastrointestinal tracts of cats. Further analyses are currently being conduct to understand this phenomenon. Pets are natural reservoirs for several organisms, especially ExPEC strains that are potentially capable of infecting human beings, which is a reason for concern (Johnson et al., 2008). The present study shows the presence of virulence genes characteristic of ExPEC strains in bacterial isolates from non-diarrheic and diarrheic cats, as well as cats with UTI.

Keywords: pet, cat, ExPEC,STEC, adhesins, virulence gene

\section{RESUMO}

Determinadas linhagens de Escherichia coli comportam-se como patógenos em gatos, causando doenças gastrointestinais e extraintestinais. Neste estudo, foram utilizadas 205 cepas de E. coli isoladas de amostras de fezes provenientes de 19 gatos diarreicos e de 21 gatos não diarreicos, e três amostras de urina provenientes de gatos com infecção do trato urinário (ITU). Essas cepas foram testadas pela técnica de reação em cadeia da polimerase com múltiplos iniciadores para a detecção da presença de genes codificadores de adesinas (pap, sfa $e$ afa), assim como para a detecção dos genes produtores da toxina Shiga-like (stx1 e stx2) e do gene da intimina (eae). Oitenta e dois isolados possuíam genes codificadores de adesinas, dos quais 11 apresentaram o gene pap, 41 apresentaram o gene sfa $e 27$ apresentaram uma combinação dos genes pap + sfa. Nenhuma das cepas examinadas apresentou os genes stx1, stx2 ou afa. Três isolados provenientes de um gato diarreico apresentaram uma combinação dos genes sfa + eae. Animais de companhia (pets) são reservatórios naturais para diversos organismos, especialmente linhagens ExPEC, as quais são potencialmente capazes de infectar seres humanos, o que representa um motivo de grande preocupação.

Palavras-chave: pet, gato, ExPEC, STEC, adesinas, genes de virulência

\section{ACKNOWLEDGEMENTS}

The authors thank FAPESP for financial support to the laboratory.

\section{REFERENCES}

BENTANCOR A.; RUMI, M.V.; GENTILINI, M.V. et al. Shiga toxin-producing and attaching and effacing Escherichia coli in cats and dogs in a high hemolytic uremic syndrome incidence region in Argentina. FEMS Microbiol. Lett., v.267, p.251-256, 2007.
BEUTIN, L. Escherichia coli as a pathogen in dogs and cats. Vet. Res., v.30, p.285-298, 1999.

CHINA, B.; PIRSON, V.; MAINIL, J. Typing of bovine attaching and effacing Escherichia coli by multiplex in vitro amplification of virulenceassociated genes. Appl. Environ. Microbiol., v.62, p.3462-3465, 1996.

FÉRIA, C.; MACHADO, J.; CORREIA, J.D. et al. Virulence genes and $\mathrm{P}$ fimbriae PapA subunit diversity in canine and feline uropathogenic Escherichia coli. Vet. Microbiol., v.82, p.81-89, 2001. 
GOFFAUX, F.; CHINA, B.; JANSSEN, B. et al. Genotypic characterization of enteropathogenic Escherichia coli (EPEC) isolated in Belgium from dogs and cats. Res. Microbiol., v.15, p.865$871,2000$.

JOHNSON, J.R.; CLABOTS, C.; KUSKOWSKI, M.A. Multiple-host sharing, long-term persistence and virulence of Escherichia coli clones from human and animal household members. J. Clin. Microbiol., v. 46, p.40784082, 2008.

JOHNSON, J.R.; DELAVARI, P.; STELL A.L. et al. Molecular comparison of extraintestinal Escherichia coli isolates of the same electrophoretic lineages from humans and domestic animals. J. Infect. Dis., v.183, p.154159,2001

JOHNSON, J.R.; STELL, A.L. Extended virulence genotypes of Escherichia coli strains from patients with urosepsis in relation to phylogeny and host compromise. J. Infect. Dis., v.181, p.261-272, 2000.

KAPER, J.B.; NATARO, J.P.; MOBLEY, H.T. Pathogenic Escherichia coli. Nature Rev. Microbiol., v.2, p.123-140, 2004.
KONEMAN, E.W.; ALLEN, S.D.; JANDA, W.M. et al. Color Atlas and Textbook of diagnostic microbiology. 5.ed. Philadelphia: Lippincott Company, 1997. p.363-393.

KRAUSE, G.; ZIMMERMANN, S.; BEUTIN, L. Investigation of domestic animals and pets as a reservoir for intimin-(eae) gene positive Escherichia coli types. Vet. Microbiol., v.106, p.87-95, 2005.

LE BOUGUENEC, C.; ARCHAMBAUD, M.; LABIGNE, A. Rapid and specific detection of the pap, afa and $s f a$ adhesion-encoding operons in uropathogenic Escherichia coli strains by polymerase chain reaction. J. Clin. Microbiol., v.30, p.1189-1193, 1992.

MORATO, E.P.; LEOMIL, L.; BEUTIN, L. et al. Domestic cats constitute natural reservoir of human enteropathogenic Escherichia coli types. Zoonoses Pub. Health, v.56, p.229-237, 2009.

YURI, K.; NAKATA, K.; KATAE, H. et al. Distribution of uropathogenic virulence factors among Escherichia coli strains isolated from dogs and cats. J. Vet. Med. Sci., v.60, p.287-290, 1998. 